\title{
Mechanisms of Double-Bond Isomerization Reactions of n-Butene on Different Lewis Acids
}

Fengjiao Yi ${ }^{\mathrm{a}, \mathrm{c}}$, Peng He ${ }^{\mathrm{b}}$, Huimin Chen ${ }^{\mathrm{e}}$, Yurong $\mathrm{He}^{\mathrm{a}, \mathrm{d}, *}$, Zhichao Tao ${ }^{\mathrm{b}}$, Tao $\mathrm{Li}^{\mathrm{a}, \mathrm{c}}$, Guoyan Zhao ${ }^{\mathrm{b}}$, Yifeng Yun ${ }^{\mathrm{b}}$, Xiaodong Wen ${ }^{\mathrm{a}, \mathrm{b}}$, Yong Yang ${ }^{\mathrm{a}, \mathrm{b}}, *$, Yongwang $\mathrm{Li}^{\mathrm{a}}$, b

${ }^{a}$ State Key Laboratory of Coal Conversion, Institute of Coal Chemistry, Chinese Academy of Sciences, Taiyuan 030001, P.R. China

${ }^{\mathrm{b}}$ National Energy Research Center for Clean Fuels, Synfuels China Co., Ltd., Beijing 101400, P.R. China

${ }^{\mathrm{c}}$ University of Chinese Academy of Sciences, Beijing 100049, P.R. China

${ }^{\mathrm{d}}$ Beijing Advanced Innovation Center for Materials Genome Engineering, Beijing Information S \& T University, Beijing 101400, P. R. China

${ }^{\mathrm{e}}$ Chemistry and Chemical Engineering Guangdong Laboratory, Shantou,515031, P.R. China

*Corresponding author: yyong@sxicc.ac.cn (Yong Yang), yurong12@foxmail.com (Yurong He) 


\section{Contents}

Table S1. Textural properties of different samples.

Table S2. IR bands assignments of gas butenes.

Table S3. IR bands assignment of $n$-butene adsorbed on two kinds of LASs.

Table S4. IR spectra of alkoxyl group of butenes adsorbed on different samples.

Table S5. Composition of products in C-wt $\%$ for $c i s-2$-butene isomerization reactions on $\mathrm{Si}-\beta$.

Table S6. Composition of products in C-wt\% for trans-2-butene isomerization reactions Si- $\beta$.

Table S7. Composition of products in C-wt $\%$ for cis-2-butene isomerization reaction on $\mathrm{AlCl}_{3} @ \gamma-\mathrm{Al}_{2} \mathrm{O}_{3}$.

Table S8. Composition of products in C-wt $\%$ for trans-2-butene isomerization reaction on $\mathrm{AlCl}_{3} @ \gamma-\mathrm{Al}_{2} \mathrm{O}_{3}$.

Table S9. Composition of products in C-wt $\%$ for $n$-butene isomerization on Si- $\beta$ with different WHSVs.

Table S10. Composition of products in C-wt $\%$ for $n$-butene isomerization on $\mathrm{AlCl}_{3} @ \gamma-\mathrm{Al}_{2} \mathrm{O}_{3}$ with different WHSVs.

Fig. S1. Powder XRD patterns of samples (a) Si- $\beta$ and (b) $\mathrm{AlCl}_{3} @ \gamma-\mathrm{Al}_{2} \mathrm{O}_{3}$.

Fig. S2. SEM images of Si- $\beta$ and $\mathrm{AlCl}_{3} @ \gamma-\mathrm{Al}_{2} \mathrm{O}_{3}$.

Fig. S3. HAADF-STEM images and mapping of chloride in $\mathrm{AlCl}_{3} @ \gamma-\mathrm{Al}_{2} \mathrm{O}_{3}$.

Fig. S4. Acidic properties of two samples upon $\mathrm{NH}_{3}-\mathrm{TPD}$.

Fig. S5. DRIFT spectra of gas butene isomers.

Fig. S6. DRIFT spectra of cis-2-butene adsorbed on $\mathrm{Si}-\beta$ and $\mathrm{AlCl}_{3} @ \gamma-\mathrm{Al}_{2} \mathrm{O}_{3}$ at $30{ }^{\circ} \mathrm{C}$.

Fig. S7. DRIFT spectra of trans-2-butene adsorbed on $\mathrm{Si}-\beta$ and $\mathrm{AlCl}_{3} @ \gamma-\mathrm{Al}_{2} \mathrm{O}_{3}$ at $30{ }^{\circ} \mathrm{C}$.

Fig. S8. Construction of Si- $\beta$ catalyst model: (a) single crystal structure of Si- $\beta$ with BEA topology; (b) top view of Si- $\beta$ (001) slab model; (c) side view of Si- $\beta$ slab model. Golden, red, and white balls represent $\mathrm{Si}, \mathrm{O}$, and $\mathrm{H}$ atoms, respectively. Blue balls represent $\mathrm{Si}$ site defects.

Fig. S9. (a) Structure of silanol nest shown in $p(2 \times 2 \times 1)$ supercells of (001) surface; (b) silanol nest defect consisting of two silanols and two suspended oxygen atoms. Golden, red, and white bed on $\mathrm{Si}-\beta$ and $\mathrm{AlCl}_{3} @ \gamma-\mathrm{Al}_{2} \mathrm{O}_{3}$ at $30{ }^{\circ} \mathrm{C}$.

Fig. S10. Construction of $\mathrm{AlCl}_{3} @ \gamma-\mathrm{Al}_{2} \mathrm{O}_{3}$ catalyst model: (a) single-crystal structure of $\mathrm{AlCl}_{3}$ and cleavage position for building surface with both $\mathrm{Al}$ and $\mathrm{Cl}$ atom exposure; (b) top view of $\mathrm{AlCl}_{3}$ (100) slab model; (c) side view of $\mathrm{AlCl}_{3}$ (100) slab model.

Fig. S11. DRIFT spectra of alkoxyl group of $n$-butene adsorbed on Si- $\beta$ and $\mathrm{AlCl}_{3} @ \gamma-\mathrm{Al}_{2} \mathrm{O}_{3}$.

Fig. S12. Energy profiles of $n$-butene isomerization reactions obtained from DFT calculations on 
LAS of silanol nest, the energy barriers are given in the parentheses. The structures of the AD-AB intermediates (Alkyl-1 and Alkyl-2), the initial and final structures of cis-trans isomerization (cis-2-Butene and trans-2-Butene).

Fig. S13. DRIFT spectra of $n$-butene adsorbed on sample Si- $\beta$ at $30^{\circ} \mathrm{C}$ in a closed system.

Fig. S14. (a) Energy profiles of $n$-butene isomerization reactions obtained from DFT calculations on LAS of $\mathrm{AlCl}_{3} @ \gamma-\mathrm{Al}_{2} \mathrm{O}_{3}$, the energy barriers are given in the parentheses; (b) the structures in $\mathrm{AD}-\mathrm{AB}$-cis route; (c) the structures in $\mathrm{AD}-\mathrm{AB}$-trans route; (d) the structures in cis-trans isomerization reaction.

Fig. S15. DRIFT spectra of alkoxyl group of cis-2-butene adsorbed on Si- $\beta$ and $\mathrm{AlCl}_{3} @ \gamma-\mathrm{Al}_{2} \mathrm{O}_{3}$ at $30{ }^{\circ} \mathrm{C}$.

Fig. S16. DRIFT spectra of alkoxyl group of trans-2-butene adsorbed on Si- $\beta$ and $\mathrm{AlCl}_{3} @ \gamma-\mathrm{Al}_{2} \mathrm{O}_{3}$ at $30^{\circ} \mathrm{C}$.

Fig. S17. DRIFT spectra of trans-2-butene adsorbed on (a) Si- $\beta$ at $100{ }^{\circ} \mathrm{C}$ in open system and (b) $\mathrm{AlCl}_{3} @ \gamma-\mathrm{Al}_{2} \mathrm{O}_{3}$ at $60{ }^{\circ} \mathrm{C}$ in closed system. From top to bottom in each panel: (a) 0.5, 2.5, 3, 4, 5, and $6 \mathrm{~min}$; and (b) 0.5, 1, 5, 10, and $15 \mathrm{~min}$.

Fig. S18. Chromatographs of $n$-butene isomerization reactions on $\mathrm{SiO}_{2}$ and $\gamma-\mathrm{Al}_{2} \mathrm{O}_{3}$ at $100^{\circ} \mathrm{C}$ with a WHSV of $0.2 \mathrm{~h}^{-1}$.

Fig. S19. In situ FI-IR spectra of $n$-butene feeding on Si- $\beta$ continuously at $100^{\circ} \mathrm{C}$ with a WHSV of $0.75 \mathrm{~h}^{-1}$. From bottom to top: 1-5, 10, 20, 25, 20, 35, 30 and $45 \mathrm{~min}$.

Fig. S20. Chromatographs of $n$-butene, cis-2-butene and trans-2-butene isomerization reactions on Si- $\beta$-origin at $100^{\circ} \mathrm{C}$ with a WHSV of $0.2 \mathrm{~h}^{-1}$.

Fig. S21. TG curves of catalysts (a) Si- $\beta$ and (b) $\mathrm{AlCl}_{3} @ \gamma-\mathrm{Al}_{2} \mathrm{O}_{3}$ after reaction for $3.4 \mathrm{~h}$. The weight loss percentages over temperature $150{ }^{\circ} \mathrm{C}$ are labled. 
Table S1. Textural properties of different samples.

\begin{tabular}{cccccc}
\hline \multirow{2}{*}{ Sample } & $\mathrm{Si} / \mathrm{Al}^{\mathrm{a}}$ & \multicolumn{3}{c}{ Surface area $\left(\mathrm{m}^{2} / \mathrm{g}\right)^{\mathrm{b}}$} & \multirow{2}{*}{$\begin{array}{c}\text { Micropore Volume } \\
\left(\mathrm{cm}^{3} / \mathrm{g}\right)\end{array}$} \\
\cline { 3 - 5 } & & $\mathrm{S}_{\mathrm{BET}}$ & $\mathrm{S}_{\text {mic }}$ & $\mathrm{S}_{\mathrm{ext}}$ & 0.17 \\
\hline $\mathrm{Si}-\beta$ & $>1200$ & 453.1 & 341.7 & 111.3 & 0.01 \\
$\mathrm{AlCl}_{3} @ \gamma-\mathrm{Al}_{2} \mathrm{O}_{3}$ & - & 120.0 & 16.2 & 103.9 & 0.9 \\
\hline
\end{tabular}

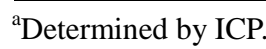

${ }^{\mathrm{b}}$ Surface areas obtained by the BET method.

${ }^{\mathrm{c}}$ Calculated from the t-plot.

Table S2. IR bands assignments of gas butenes.

\begin{tabular}{|c|c|c|c|}
\hline \multirow{2}{*}{ Vibration } & \multicolumn{3}{|c|}{ Bands assignment } \\
\hline & $n$-butene & cis-2-butene & trans-2-butene \\
\hline $\mathrm{v}_{\mathrm{as}}\left(\mathrm{CH}_{3}\right)$ & 2976 & $2997 / 2985 / 2976 / 2947$ & $2978 / 2964 / 2949$ \\
\hline $\mathrm{v}_{\mathrm{as}}\left(\mathrm{CH}_{2}\right)$ & 2939 & - & - \\
\hline$v_{s}\left(\mathrm{CH}_{3}\right)$ & 2900 & $2935 / 2926$ & $2937 / 2924$ \\
\hline $2 \delta_{\text {as }}\left(\mathrm{CH}_{3}\right)$ & - & 2900/2889/2870 & $2895 / 2881 / 2866$ \\
\hline$v_{s}\left(\mathrm{CH}_{2}\right)$ & 2879 & - & - \\
\hline$v_{\text {as }}\left(=\mathrm{CH}_{2}\right)$ & $3097 / 3088 / 3082$ & - & \\
\hline$v_{s}\left(=\mathrm{CH}_{2}\right)$ & 2985 & - & - \\
\hline$v(=\mathrm{CH})$ & - & $3039 / 3024$ & $3034 / 3016$ \\
\hline
\end{tabular}

Table S3. IR bands assignment of $n$-butene adsorbed on two kinds of LASs.

\begin{tabular}{|c|c|c|c|c|c|}
\hline \multirow{3}{*}{ Vibration } & \multicolumn{5}{|c|}{ Bands assignment (surface species) } \\
\hline & \multicolumn{3}{|c|}{$\mathrm{Si}-\beta$} & \multicolumn{2}{|c|}{$\mathrm{AlCl}_{3} @ \gamma-\mathrm{Al}_{2} \mathrm{O}_{3}$} \\
\hline & $\pi$-complex & $\begin{array}{l}\text { allylic } \\
\text { species }\end{array}$ & $\begin{array}{l}\text { alkyl } \\
\text { group }\end{array}$ & $\pi$-complex & $\begin{array}{l}\text { allylic } \\
\text { species }\end{array}$ \\
\hline$v_{\mathrm{as}}\left(-\mathrm{CH}_{3}\right)$ & 2976 & 2964 & 2958 & 2972 & 2962 \\
\hline$v_{\text {as }}\left(-\mathrm{CH}_{2}\right)$ & 2937 & 2922 & 2929 & $2945 / 2939$ & 2914 \\
\hline $\mathrm{v}_{\mathrm{s}}\left(-\mathrm{CH}_{3}\right)$ & - & 2877 & 2875 & - & 2879 \\
\hline $\mathrm{v}_{\mathrm{s}}\left(-\mathrm{CH}_{2}\right)$ & - & 2852 & 2864 & - & 2856 \\
\hline $\mathrm{v}_{\mathrm{as}}\left(=\mathrm{CH}_{2}\right)$ & 3080 & 3064 & & 3086 & 3064 \\
\hline
\end{tabular}


Table S4. IR spectra of alkoxyl group of butenes adsorbed on different samples.

\begin{tabular}{|c|c|c|c|c|c|c|c|c|c|}
\hline \multirow{4}{*}{$\frac{\text { Sample }}{\text { Si- } \beta}$} & \multirow{2}{*}{\multicolumn{9}{|c|}{$\begin{array}{c}1300 \mathrm{~cm}^{-1}-1000 \mathrm{~cm}^{-1} \text { skeletal stretching mode of alkoxy group } \\
\left(\text { Wavenumber } / \mathrm{cm}^{-1}\right)\end{array}$}} \\
\hline & & & & & & & & & \\
\hline & \multicolumn{3}{|c|}{$n$-butene } & \multicolumn{3}{|c|}{ cis-2-butene } & \multicolumn{3}{|c|}{ trans-2-butene } \\
\hline & 1265 & - & 1167 & 1267 & - & 1174 & 1255 & - & 1163 \\
\hline $\mathrm{AlCl}_{3} @ \gamma-\mathrm{Al}_{2} \mathrm{O}_{3}$ & - & - & - & - & - & - & - & - & - \\
\hline
\end{tabular}

Table S5. Composition of products in C-wt $\%$ for cis-2-butene isomerization reactions on Si- $\beta$.

\begin{tabular}{cccccccc}
\hline \multirow{2}{*}{$\begin{array}{c}\text { TOS } \\
(\mathrm{h})\end{array}$} & $\begin{array}{c}\text { Conversion } \\
(\%)\end{array}$ & butane & $n$-butene & trans-2-butene & isobutene & $\mathrm{C} 8$ & trans /n \\
\hline & 71.2 & 0.05 & 10.3 & 88.0 & 0.1 & 1.4 & 8.54 \\
0.33 & 62.5 & 0.04 & 13.3 & 83.4 & 0.2 & 3.0 & 6.27 \\
1.05 & 52.6 & 0.04 & 17.6 & 77.2 & 0.2 & 4.9 & 4.39 \\
1.77 & 43.8 & 0.05 & 22.7 & 71.0 & 0.2 & 6.0 & 3.13 \\
2.49 & 35.6 & 0.07 & 28.7 & 64.6 & 0.2 & 6.4 & 2.25 \\
3.21 & 31.6 & 0.07 & 32.1 & 61.6 & 0.1 & 6.1 & 1.92 \\
3.93 & & 0.07 &
\end{tabular}

Reaction condition: $\mathrm{Si}-\beta(1 \mathrm{~g}), 10 \%$ cis-2-butene in helium, $\mathrm{T}=100{ }^{\circ} \mathrm{C}, \mathrm{WHGV}=0.2 \mathrm{~h}^{-1}$

Table S6. Composition of products in C-wt\% for trans-2-butene isomerization reactions Si- $\beta$.

\begin{tabular}{cccccccc}
\hline \multirow{2}{*}{$\begin{array}{c}\text { TOS } \\
(\mathrm{h})\end{array}$} & Conversion & \multicolumn{7}{c}{ Selectivity(\%) } \\
\cline { 3 - 7 } & $(\%)$ & butane & cis-2-butene & $n$-butene & isobutene & $\mathrm{C} 8$ & cis/n \\
\hline 0.33 & 35.3 & 0.7 & 77.3 & 19.2 & 0.2 & 2.7 & 4.03 \\
1.05 & 33.9 & 0.5 & 74.8 & 19.5 & 0.4 & 4.8 & 3.84 \\
1.77 & 29.3 & 0.6 & 72.4 & 20.7 & 0.5 & 5.8 & 3.50 \\
2.49 & 24.9 & 0.6 & 70.2 & 22.3 & 0.5 & 6.3 & 3.15 \\
3.21 & 21.1 & 0.8 & 68.5 & 24.3 & 0.2 & 6.3 & 2.82 \\
3.93 & 18.7 & 0.9 & 67.3 & 25.8 & 0.2 & 5.9 & 2.61 \\
\hline
\end{tabular}

Reaction condition: $\mathrm{Si}-\beta(1 \mathrm{~g}), 10 \%$ trans-2-butene in helium, $\mathrm{T}=100{ }^{\circ} \mathrm{C}, \mathrm{WHGV}=0.2 \mathrm{~h}^{-1}$ 
Table S7. Composition of products in C-wt $\%$ for cis-2-butene isomerization reaction on $\mathrm{AlCl}_{3} @ \gamma-\mathrm{Al}_{2} \mathrm{O}_{3}$.

\begin{tabular}{cccccccc}
\hline \multirow{2}{*}{$\begin{array}{c}\text { TOS } \\
\text { h) }\end{array}$} & $\begin{array}{c}\text { Conversion } \\
(\%)\end{array}$ & butane & $n$-butene & trans-2-butene & isobutene & $\mathrm{C} 8$ & trans $/ \mathrm{n}$ \\
\hline 0.33 & 70.2 & 0.04 & 10.9 & 84.4 & 0.03 & 4.6 & 7.74 \\
1.05 & 66.7 & 0.04 & 12.7 & 84.0 & 0 & 3.3 & 6.61 \\
1.77 & 63.8 & 0.04 & 14.2 & 82.9 & 0 & 2.9 & 5.84 \\
2.49 & 61.3 & 0.04 & 15.6 & 81.7 & 0 & 2.6 & 5.24 \\
3.21 & 59.1 & 0.04 & 17.0 & 80.5 & 0 & 2.4 & 4.74 \\
3.93 & 57.1 & 0.04 & 18.3 & 79.4 & 0 & 2.3 & 4.34 \\
\hline Reaction condition. $\mathrm{AlCl}_{3} @ \gamma-\mathrm{Al}_{2} \mathrm{O}_{3}(1 \mathrm{~g}), 10 \%$ cis-2-butene in helium, $\mathrm{T}=100^{\circ} \mathrm{C}, \mathrm{WHGV}=0.2 \mathrm{~h}^{-1}$
\end{tabular}

Table S8. Composition of products in C-wt $\%$ for trans-2-butene isomerization reaction on $\mathrm{AlCl}_{3} @ \gamma-\mathrm{Al}_{2} \mathrm{O}_{3}$.

\begin{tabular}{cccccccc}
\hline \multirow{2}{*}{$\begin{array}{c}\text { TOS } \\
\text { (h) }\end{array}$} & Conversion & \multicolumn{7}{c}{ Selectivity $(\%)$} \\
\cline { 3 - 8 } & $(\%)$ & butane & cis-2-butene & $n$-butene & isobutene & C8 & cis/n \\
\hline 0.33 & 37.5 & 0.4 & 73.9 & 18.6 & 0 & 7.1 & 3.97 \\
1.05 & 37.3 & 0.4 & 76.1 & 18.9 & 0 & 4.6 & 4.03 \\
1.77 & 35.0 & 0.4 & 76.2 & 19.5 & 0 & 3.9 & 3.91 \\
2.49 & 34.1 & 0.4 & 76.6 & 19.6 & 0 & 3.3 & 3.90 \\
3.21 & 33.3 & 0.4 & 76.9 & 19.8 & 0 & 2.9 & 3.88 \\
3.93 & 32.5 & 0.5 & 77.1 & 19.9 & 0 & 2.6 & 3.87 \\
\hline
\end{tabular}

Reaction condition: $\mathrm{AlCl}_{3} @ \gamma-\mathrm{Al}_{2} \mathrm{O}_{3}(1 \mathrm{~g}), 10 \%$ trans-2-butene in helium, $\mathrm{T}=100{ }^{\circ} \mathrm{C}, \mathrm{WHGV}=0.2 \mathrm{~h}^{-1}$

Table S9. Composition of products in C-wt $\%$ for $n$-butene isomerization on Si- $\beta$ with different WHSVs.

\begin{tabular}{ccccccccc}
\hline WHSV & Residence & Conversion & \multicolumn{7}{c}{ Selectivity $(\%)$} \\
\cline { 5 - 9 }$\left(\mathrm{h}^{-1}\right)$ & Time $(\mathrm{h})$ & $(\%)$ & butane & cis-2-butene & trans-2-butene & isobutene & $\mathrm{C} 8$ & trans/cis \\
\hline 0.2 & 5 & 93.4 & 0.4 & 29.4 & 68.8 & 0.05 & 1.3 & 2.34 \\
0.3 & 3.33 & 92.7 & 0.3 & 33.4 & 64.7 & 0.08 & 1.5 & 1.94 \\
0.6 & 1.67 & 92.0 & 0.3 & 38.9 & 58.4 & 0.08 & 2.3 & 1.50 \\
\hline
\end{tabular}

Reaction condition: Si- $\beta(1 \mathrm{~g}), 10 \% n$-butene in helium, $\mathrm{T}=100^{\circ} \mathrm{C}$. 
Table S10. Composition of products in C-wt $\%$ for $n$-butene isomerization on $\mathrm{AlCl}_{3} @ \gamma-\mathrm{Al}_{2} \mathrm{O}_{3}$ with different WHSVs.

\begin{tabular}{ccccccccc}
\hline \multirow{2}{*}{ WHSV } & Residence & Conversion & \multicolumn{7}{c}{ Selectivity(\%) } \\
\cline { 4 - 9 } & Time $(\mathrm{h})$ & $(\%)$ & butane & cis-2-butene & trans-2-butene & isobutene & $\mathrm{C} 8$ & trans/cis \\
\hline $0.2 \mathrm{~h}^{-1}$ & 5 & 93.4 & 0.3 & 29.0 & 63.9 & 0.04 & 6.7 & 2.20 \\
$0.3 \mathrm{~h}^{-1}$ & 3.33 & 92.8 & 0.3 & 32.0 & 63.8 & 0.04 & 3.8 & 1.99 \\
$0.6 \mathrm{~h}^{-1}$ & 1.67 & 92.3 & 0.3 & 34.1 & 62.3 & 0.03 & 3.2 & 1.83 \\
\hline
\end{tabular}

Reaction condition: $\mathrm{AlCl}_{3} @ \gamma-\mathrm{Al}_{2} \mathrm{O}_{3}(1 \mathrm{~g}), 10 \% n$-butene in helium, $\mathrm{T}=100{ }^{\circ} \mathrm{C}$.
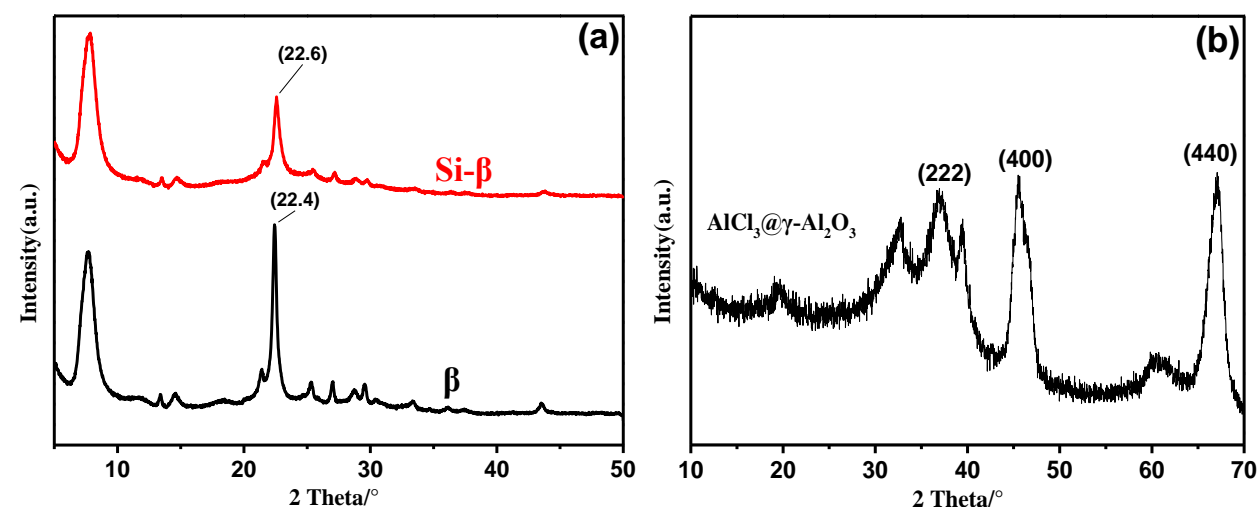

Fig. S1. Powder XRD patterns of samples (a) Si- $\beta$ and (b) $\mathrm{AlCl}_{3} @ \gamma-\mathrm{Al}_{2} \mathrm{O}_{3}$.
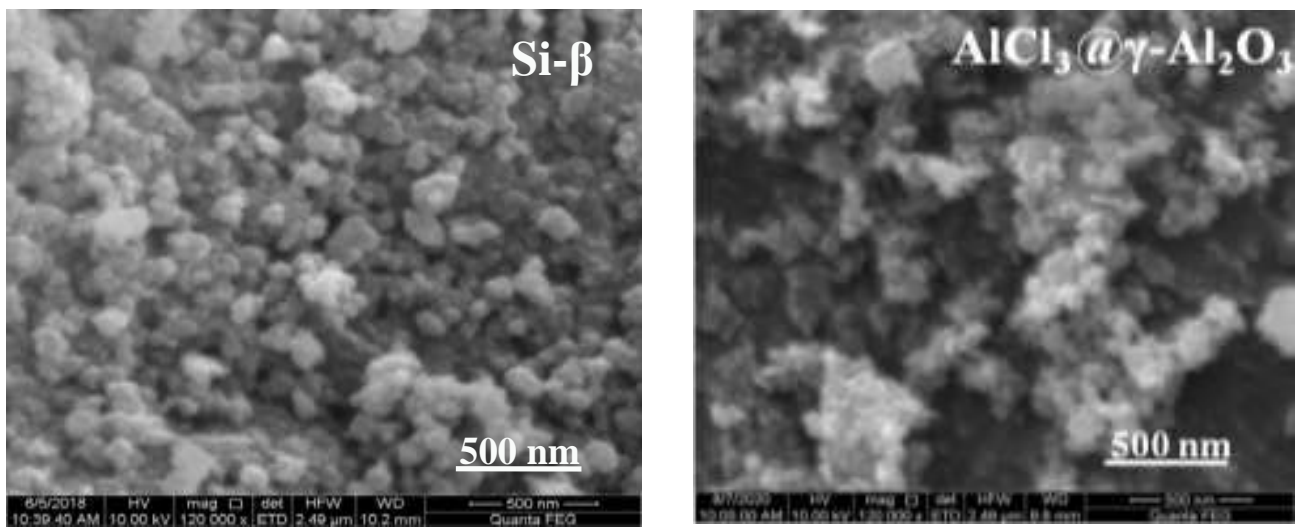

Fig. S2. SEM images of Si- $\beta$ and $\mathrm{AlCl}_{3} @ \gamma-\mathrm{Al}_{2} \mathrm{O}_{3}$. 


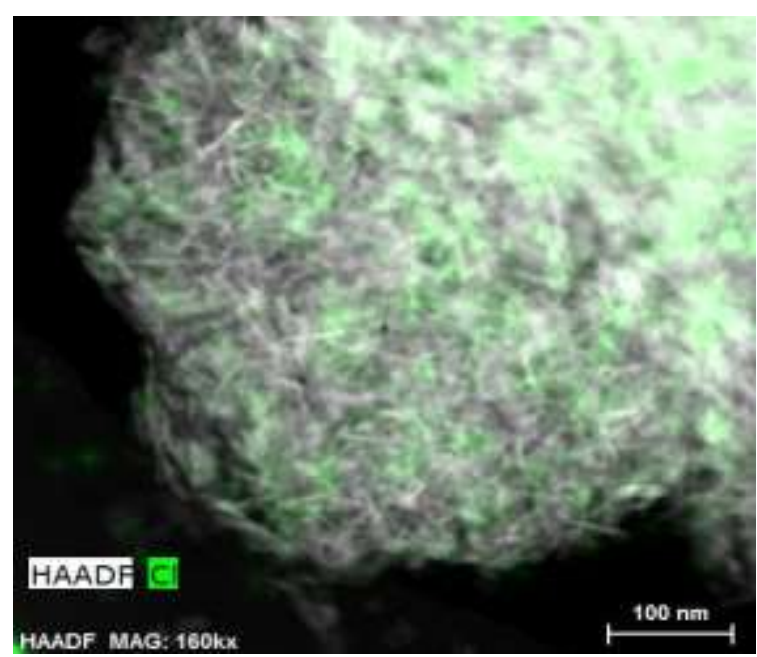

Fig. S3. HAADF-STEM images and mapping of chloride in $\mathrm{AlCl}_{3} @ \gamma-\mathrm{Al}_{2} \mathrm{O}_{3}$.

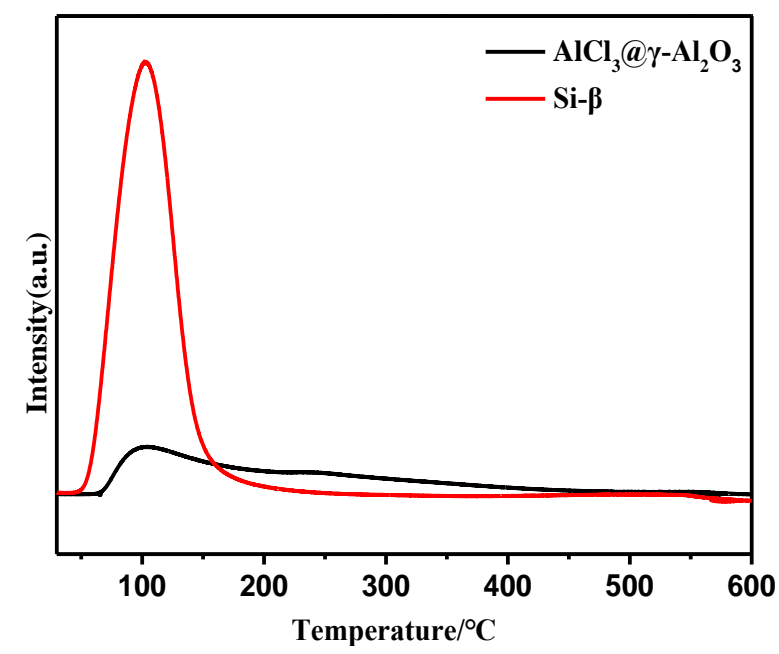

Fig. S4. Acidic properties of two samples upon $\mathrm{NH}_{3}$-TPD.
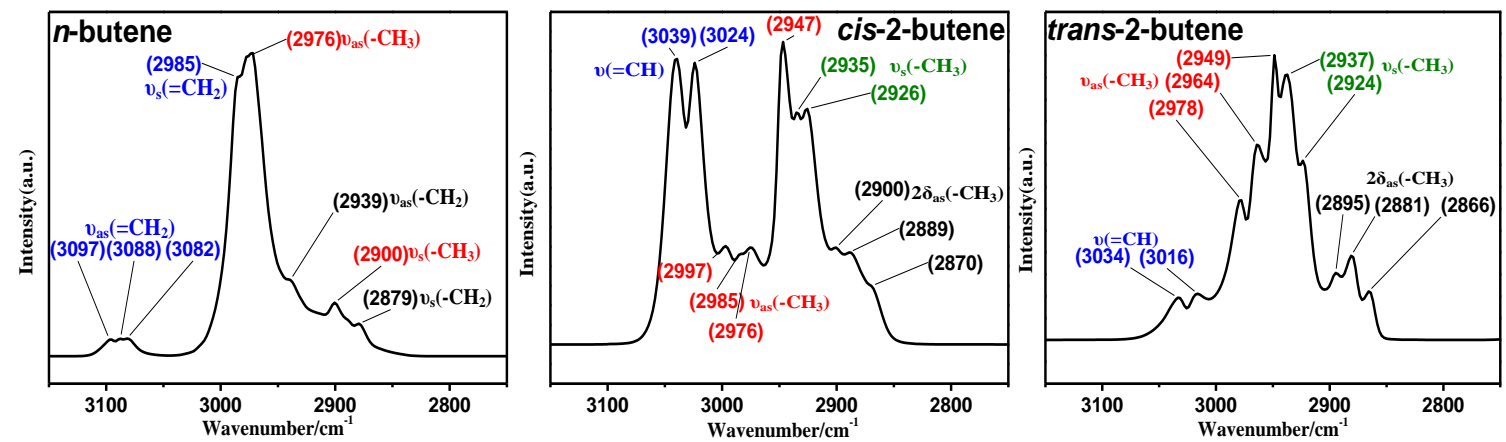

Fig. S5. DRIFT spectra of gas butene isomers.

IR spectra of four butene isomers are measured to distinguish from adsorbed butenes (Fig. S8 and Table S3). Both the three overlapping bands at 3097, 3088 and $3082 \mathrm{~cm}^{-1}$ attributed to the $\mathrm{C}-\mathrm{H}$ asymmetric stretching vibrations in the $=\mathrm{CH}_{2}$ group 
$\left(v_{\mathrm{as}}=\mathrm{CH}_{2}\right)$ in blue, and symmetric stretching vibration bands $\left(v_{\mathrm{s}}=\mathrm{CH}_{2}\right)$ at $2985 \mathrm{~cm}^{-1}$ indicate the presence of olefinic groups in $n$-butene. ${ }^{1}$ The $\mathrm{C}-\mathrm{H}$ stretching vibration bands $(v=\mathrm{CH})$ in the $=\mathrm{CH}$ group of cis-2-butene and trans-2-butene shifted to lower vibration frequency about $3030 \mathrm{~cm}^{-1}$ compared to $3090 \mathrm{~cm}^{-1}$ of $n$-butene. ${ }^{2}$ In general, $v_{\mathrm{as}}-\mathrm{CH}_{3}$ in red and $v_{\mathrm{as}}-\mathrm{CH}_{2}$ in black in gas butene isomers shift from $2960\left(\mathrm{v}_{\mathrm{as}}-\mathrm{CH}_{3}\right)$, $2927\left(v_{\mathrm{as}}-\mathrm{CH}_{2}\right), 2870\left(v_{\mathrm{s}}-\mathrm{CH}_{3}\right)$ and $2860\left(v_{\mathrm{s}}-\mathrm{CH}_{2}\right) \mathrm{cm}^{-1}$ in saturated group to higher vibration frequency, or bands of methyl split into a series of couple bands generally centred at $2960\left(v_{\mathrm{as}}-\mathrm{CH}_{3}\right)$ and $2860 \mathrm{~cm}^{-1}\left(\mathrm{v}_{\mathrm{s}}-\mathrm{CH}_{3}\right)$ effected by double bond. ${ }^{3}$ Bands in $n$-butene only shift to higher wavenumbers at $2976\left(v_{\mathrm{as}}-\mathrm{CH}_{3}\right), 2939\left(\mathrm{v}_{\mathrm{as}}-\mathrm{CH}_{2}\right), 2900$ $\left(v_{\mathrm{s}}-\mathrm{CH}_{3}\right)$ and $2879\left(v_{\mathrm{s}}-\mathrm{CH}_{2}\right) \mathrm{cm}^{-1}{ }^{4-6}$ without band split of methyl due to longer distance between methyl and double bond compared to those in 2-butene. Bands of methyl in cis-2-butene split into a series of couple bands at 2997, 2985, 2976 and $2947\left(v_{\mathrm{as}}-\mathrm{CH}_{3}\right) \mathrm{cm}^{-1}, 2935$ and $2926\left(\mathrm{v}_{\mathrm{s}}-\mathrm{CH}_{3}\right) \mathrm{cm}^{-1}$ and 2900,2889 and 2870 $\left(2 \delta_{\mathrm{as}}-\mathrm{CH}_{3}\right) \mathrm{cm}^{-1}$. Bands of methyl in trans-2-butene also split into a series of couple bands at 2978, 2964 and $2949\left(v_{\mathrm{as}}-\mathrm{CH}_{3}\right) \mathrm{cm}^{-1}, 2937$ and $2924\left(\mathrm{v}_{\mathrm{s}}-\mathrm{CH}_{3}\right) \mathrm{cm}^{-1}$ and 2895, 2881 and $2866\left(2 \delta_{\mathrm{as}}-\mathrm{CH}_{3}\right) \mathrm{cm}^{-1}$.
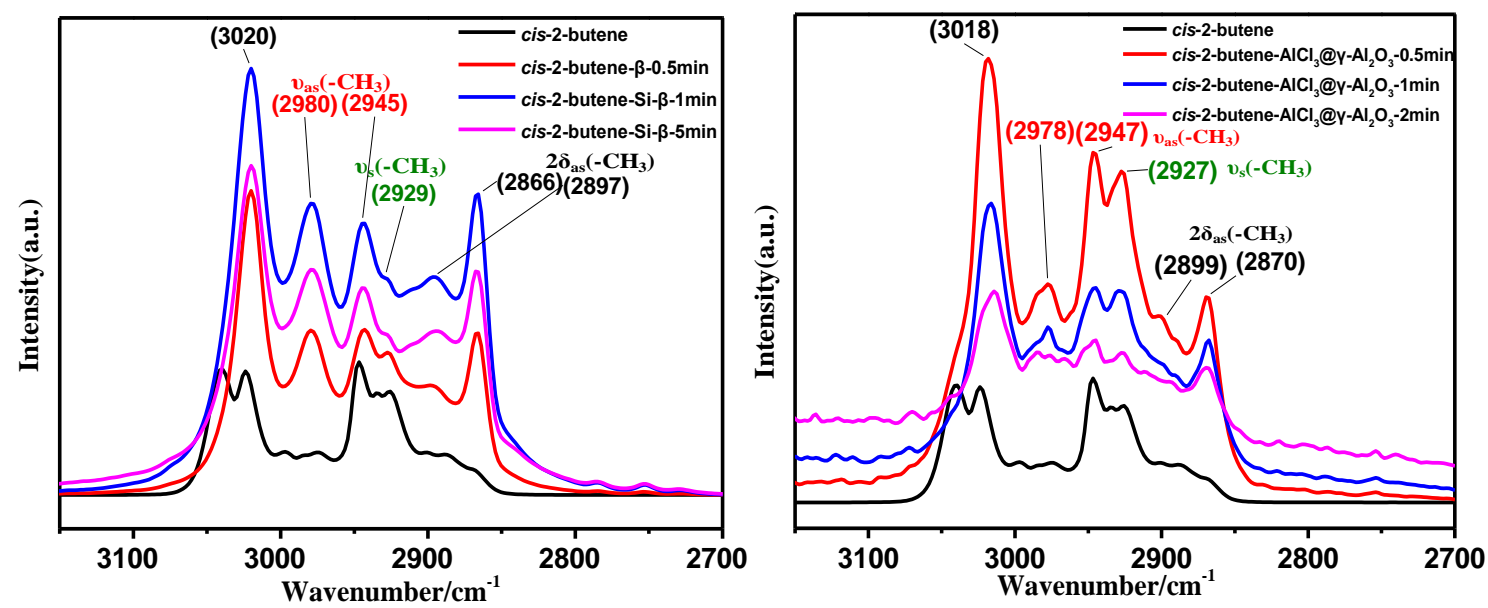

Fig. S6. DRIFT spectra of $c i s-2$-butene adsorbed on $\mathrm{Si}-\beta$ and $\mathrm{AlCl}_{3} @ \gamma-\mathrm{Al}_{2} \mathrm{O}_{3}$ at $30{ }^{\circ} \mathrm{C}$. 

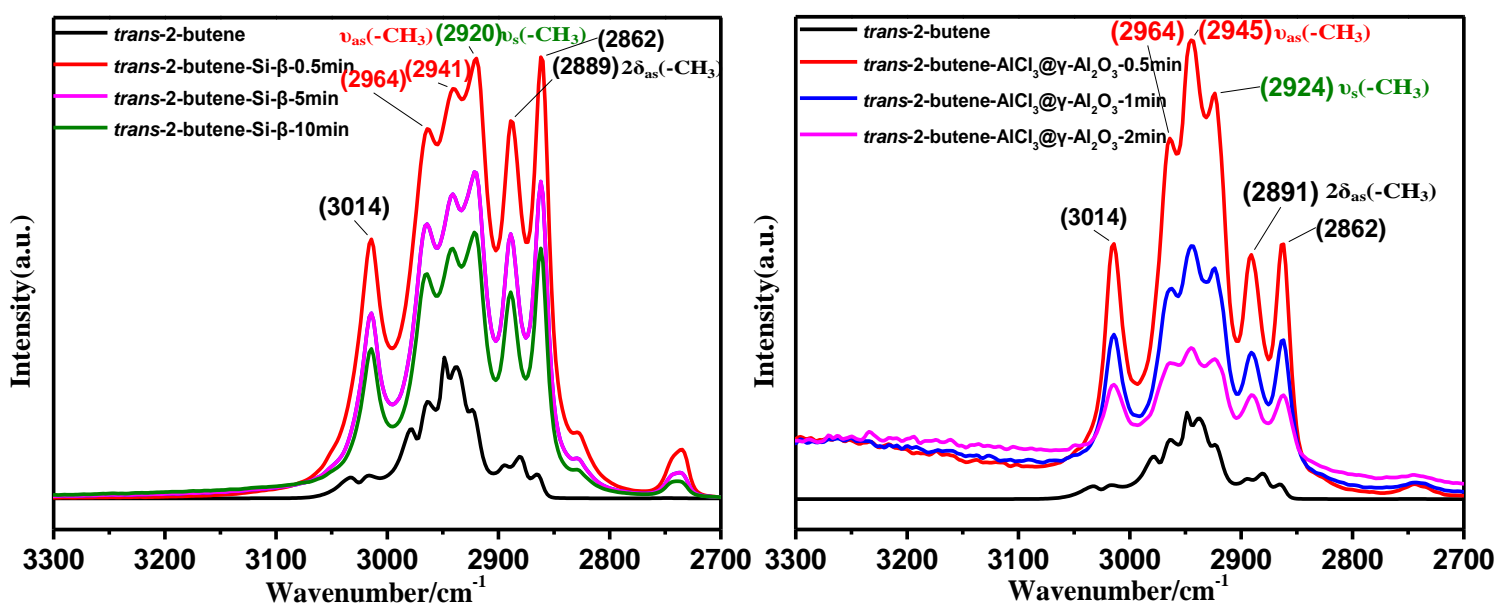

Fig. S7. DRIFT spectra of trans-2-butene adsorbed on $\mathrm{Si}-\beta$ and $\mathrm{AlCl}_{3} @ \gamma-\mathrm{Al}_{2} \mathrm{O}_{3}$ at $30^{\circ} \mathrm{C}$.

\section{DFT Calculation Models:}

As shown in Fig. S8, the $\mathrm{Si}-\beta$ catalyst was simulated by building a slab model by cleaving a zeolite $\beta$ single-crystal with the BEA topology along the (001) facet to expose the atoms inside the 12-membered ring. The suspended $\mathrm{O}$ atoms on the top and bottom surfaces were compensated for with $\mathrm{H}$ atoms. The stabilities of the $\mathrm{Si}$ atoms forming the pores are similar, ${ }^{7}$ therefore we built defect sites by deleting one $\mathrm{Si}$ atom on the pore. The four $\mathrm{O}$ atoms were compensated for with $\mathrm{H}$ atoms, to form the silanol nest (Fig. S9). A defective silanol nest was built by dehydration $\left(-\mathrm{H}_{2} \mathrm{O}\right)$ from the original silanol nest. Then, the three-membered ring (3MR) is formed and acts as the active site. A $p(1 \times 1)$ supercell of thickness of $13.42 \AA$ was used. The top half layers along with adsorbates and compensating $\mathrm{H}$ atoms were relaxed and the bottom layers were fixed in their bulk positions. The vacuum gap between the slabs was set at $15 \AA$, without counting the adsorbates. On the basis of the surface area $(12.66 \AA \times$ $12.66 \AA$ A), $2 \times 2 \times 1$ Monkhorst-Pack $k$-point grid sampling within the Brillouin zones was set.

For $\mathrm{AlCl}_{3} @ \gamma-\mathrm{Al}_{2} \mathrm{O}_{3}$ catalyst simulation a pure $\mathrm{AlCl}_{3}$ surface model was adopted because $\gamma-\mathrm{Al}_{2} \mathrm{O}_{3}$ is inert in our reaction system. $\mathrm{AlCl}_{3}$ has a rhombohedral crystal structure with the $\mathrm{P}-3 \mathrm{~m} 1$ space group and the crystallographic parameters $a=5.93 \AA$, $b=10.27 \AA, c=6.19 \AA, \alpha=\gamma=90^{\circ}, \beta=108.18^{\circ}$. As shown in Fig. S10, an $\mathrm{AlCl}_{3}$ (100) facet was built to expose both $\mathrm{Al}$ and $\mathrm{Cl}$ sites on the surface. To model the $\mathrm{AlCl}_{3}$ 
(100) surface, we used $p(1 \times 2)$ super cells containing seven layer periodic slabs, in which the adsorbates are relaxed, and the rest of the slab layers are fixed in their bulk positions because of the instability of $\mathrm{AlCl}_{3}$. On the basis of the lattice size $(10.95 \AA$ $\times 13.59 \AA$ ), $2 \times 2 \times 1 k$-point grid sampling within the Brillouin zones was set.
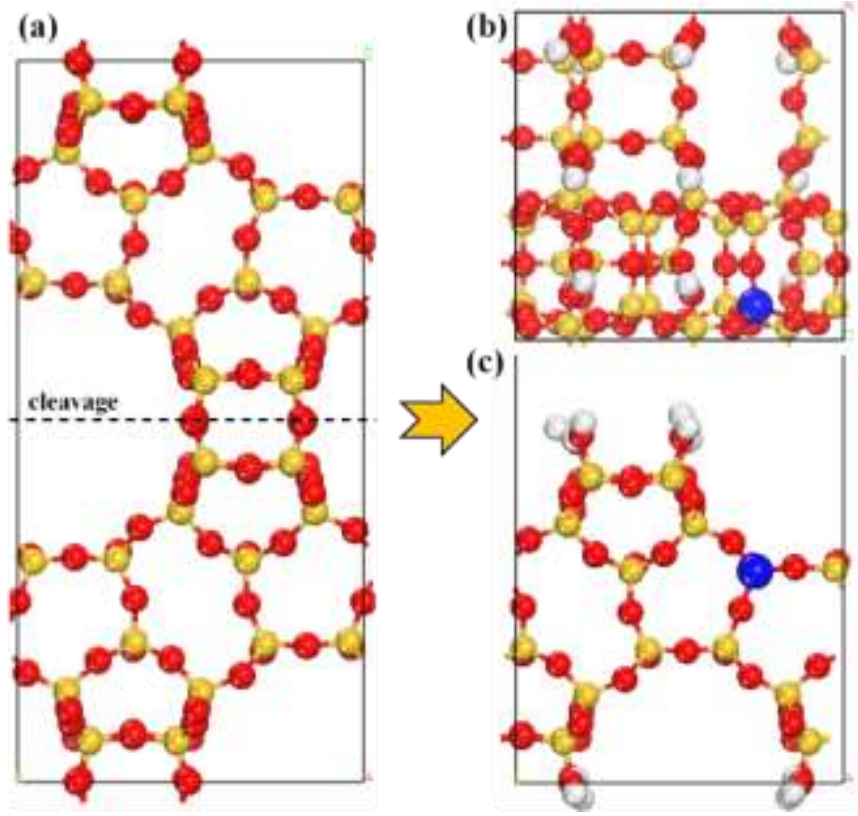

Fig. S8. Construction of Si- $\beta$ catalyst model: (a) single crystal structure of Si- $\beta$ with BEA topology; (b) top view of Si- $\beta$ (001) slab model; (c) side view of Si- $\beta$ slab model. Golden, red, and white balls represent $\mathrm{Si}, \mathrm{O}$, and $\mathrm{H}$ atoms, respectively. Blue balls represent $\mathrm{Si}$ site defects for building silanol nests.

(a)

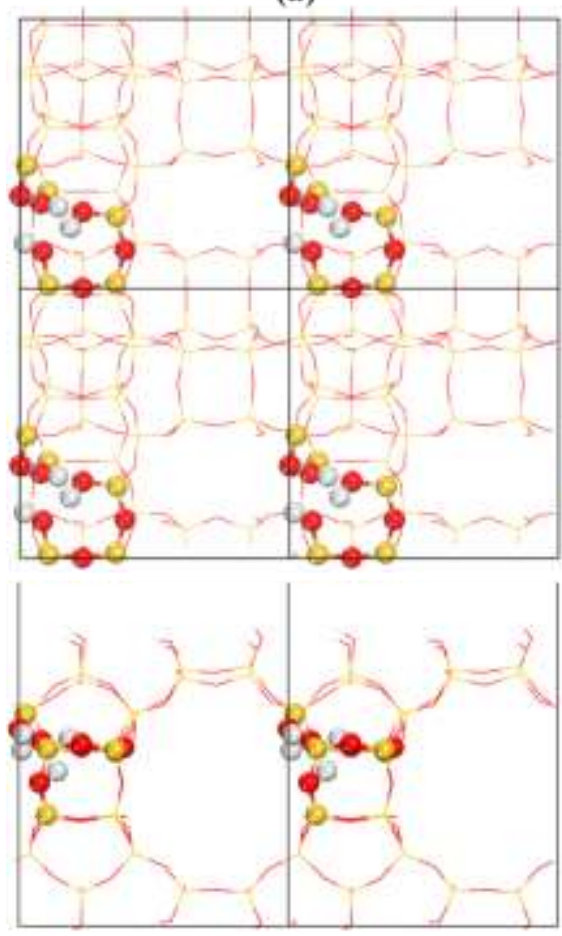

(b)
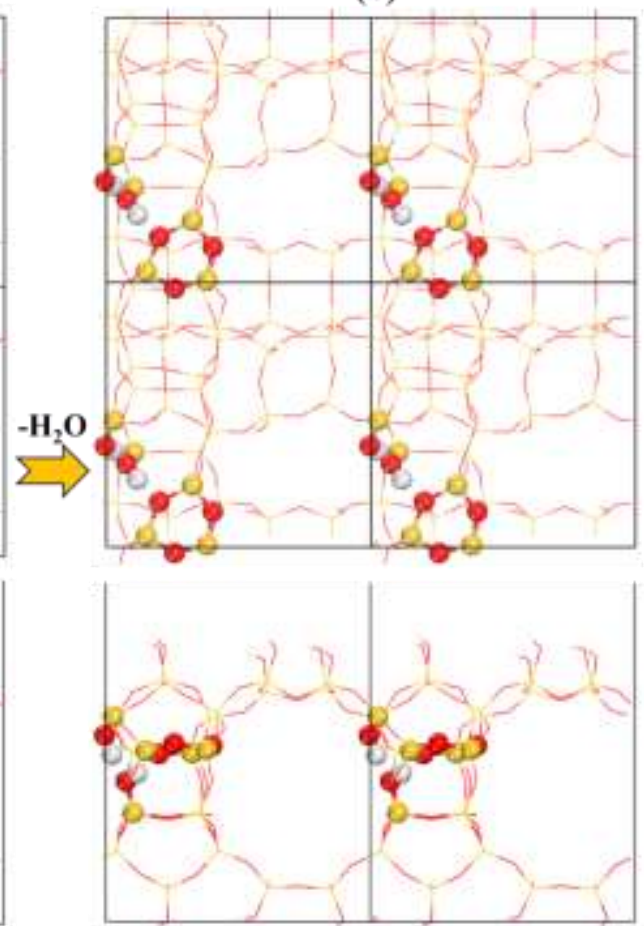
Fig. S9. (a) Structure of silanol nest shown in $p(2 \times 2 \times 1)$ supercells of (001) surface; (b) silanol nest defect consisting of two silanols and a 3MR. Golden, red, and white balls represent $\mathrm{Si}, \mathrm{O}$, and $\mathrm{H}$ atoms, respectively.

(b)

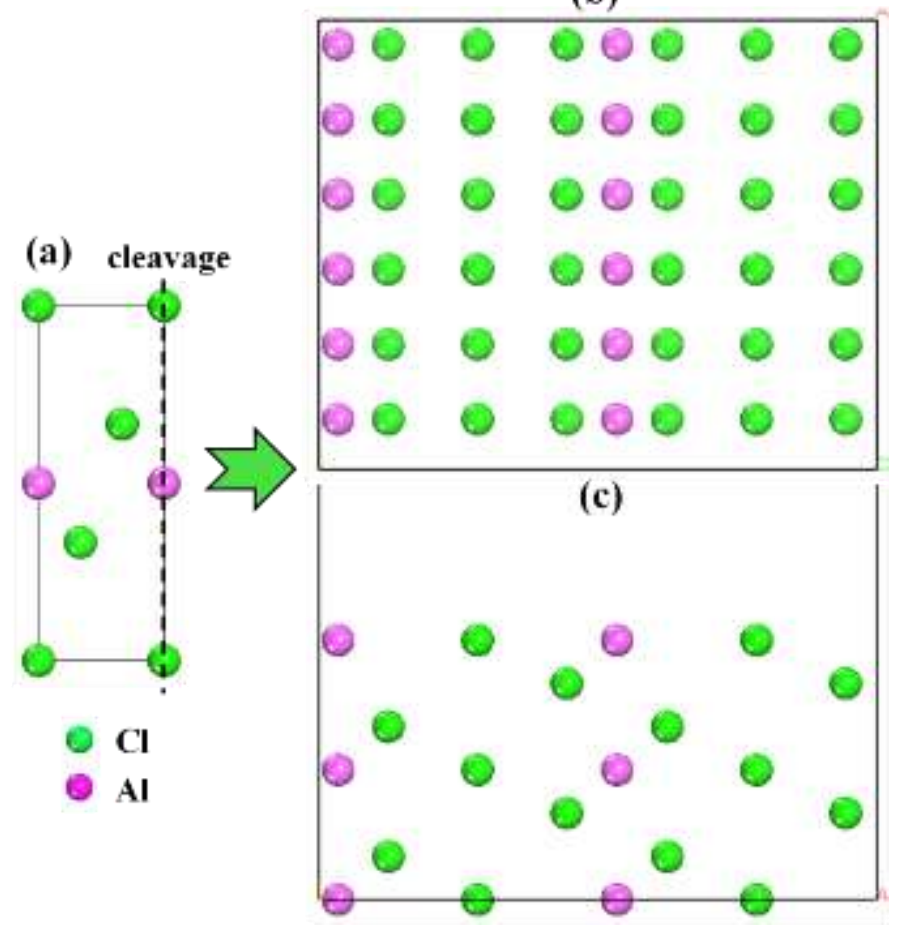

Fig. S10. Construction of $\mathrm{AlCl}_{3} @ \gamma-\mathrm{Al}_{2} \mathrm{O}_{3}$ catalyst model: (a) single-crystal structure of $\mathrm{AlCl}_{3}$ and cleavage position for building surface with both $\mathrm{Al}$ and $\mathrm{Cl}$ atom exposure; (b) top view of $\mathrm{AlCl}_{3}$ (100) slab model; (c) side view of $\mathrm{AlCl}_{3}$ (100) slab model.
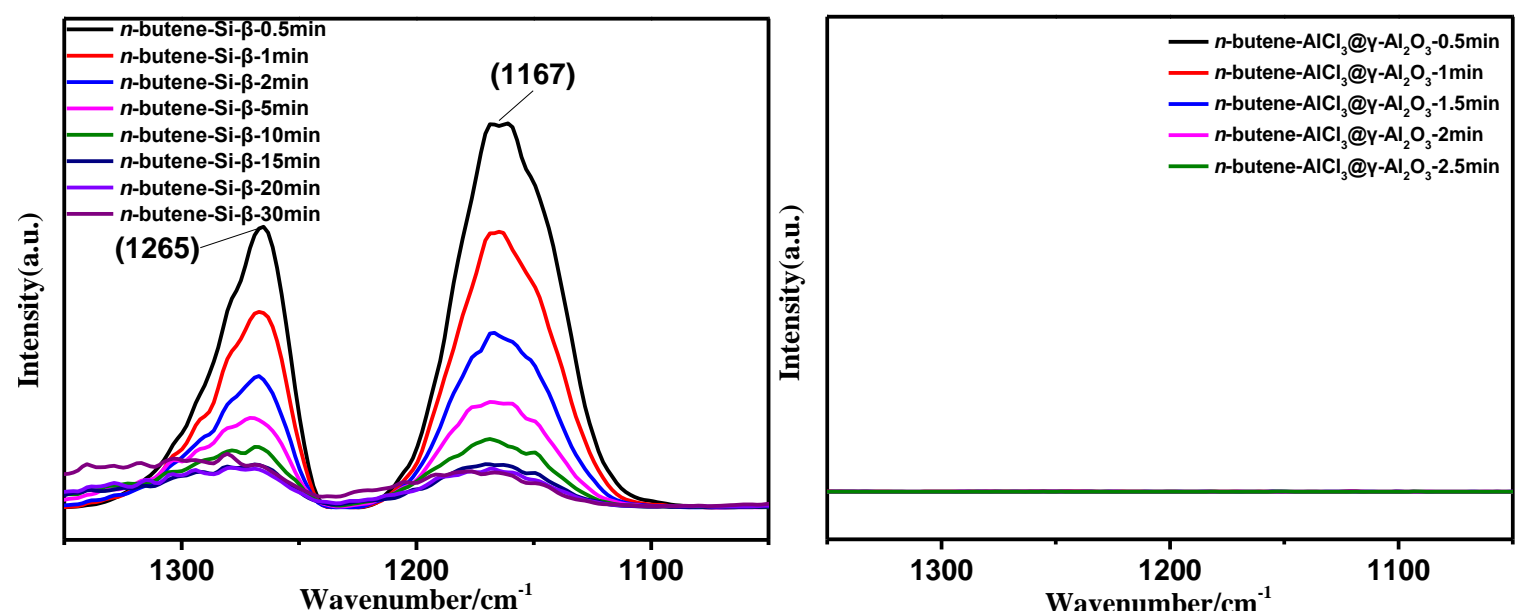

Fig. S11. DRIFT spectra of alkoxyl group of $n$-butene adsorbed on Si- $\beta$ and $\mathrm{AlCl}_{3} @ \gamma-\mathrm{Al}_{2} \mathrm{O}_{3}$. 


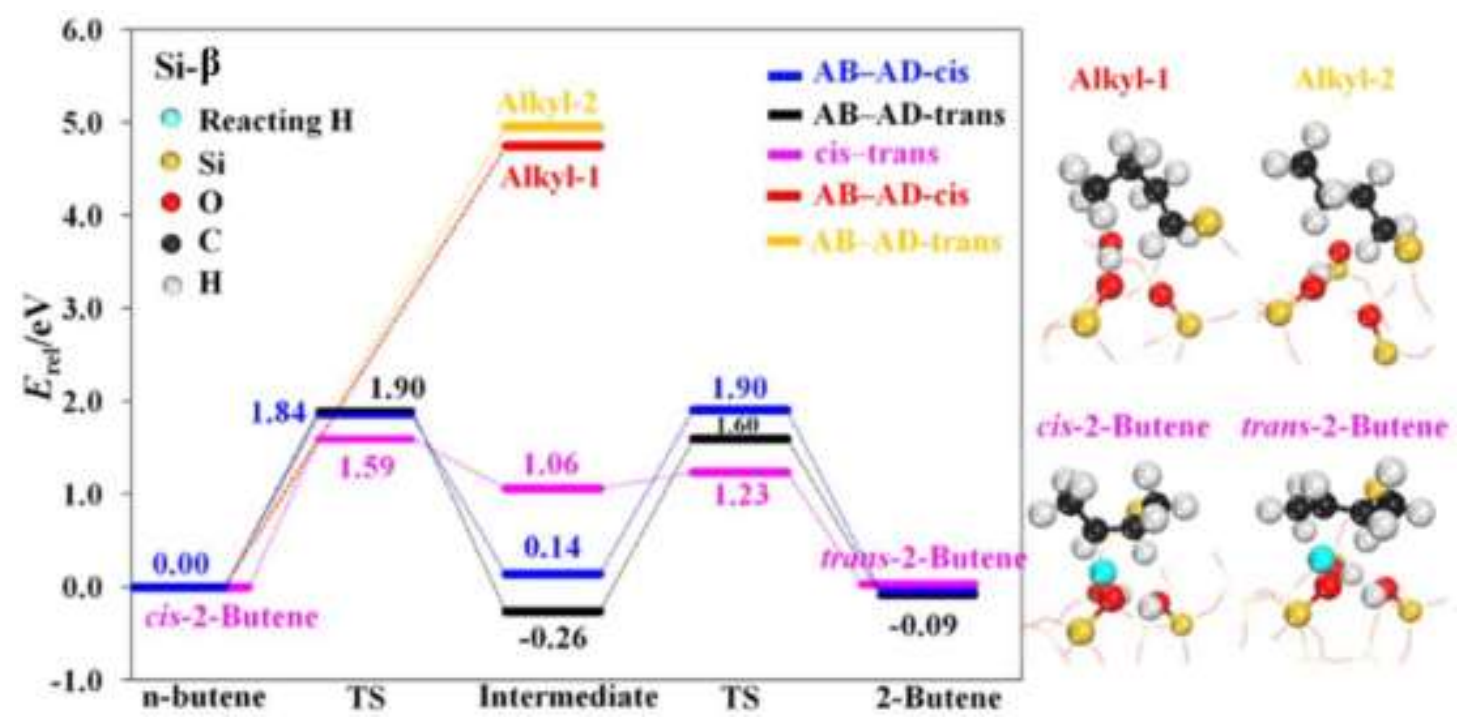

Fig. S12. Energy profiles of $n$-butene isomerization reactions obtained from DFT calculations on LAS of silanol nest, the energy barriers are given in the parentheses. The structures of the AD-AB intermediates (Alkyl-1 and Alkyl-2) and the initial and final structures of cis-trans isomerization (cis-2-Butene and trans-2-Butene) are shown in the right side of the figure.

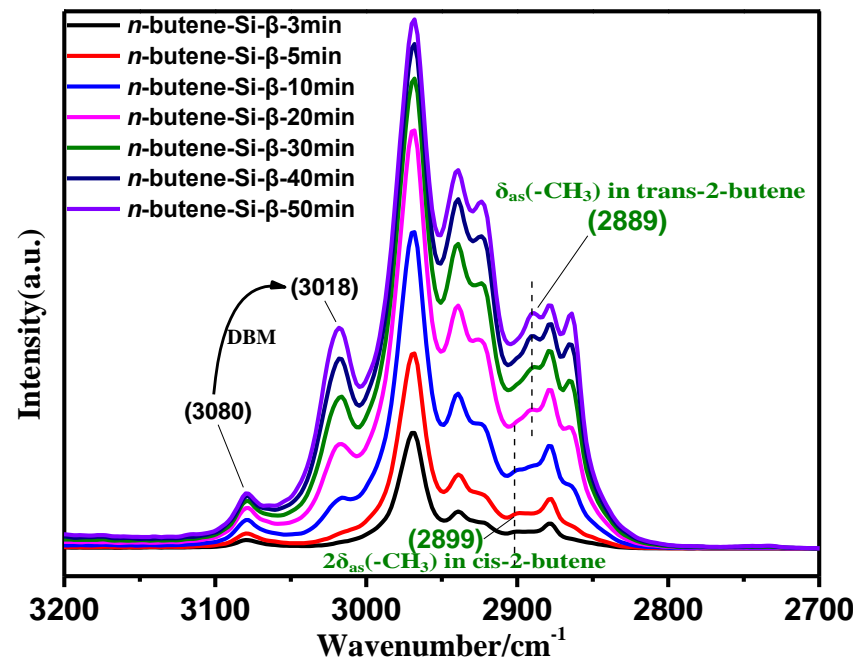

Fig. S13. DRIFT spectra of $n$-butene adsorbed on sample $\mathrm{Si}-\beta$ at $30^{\circ} \mathrm{C}$ in a closed system. 
(a)

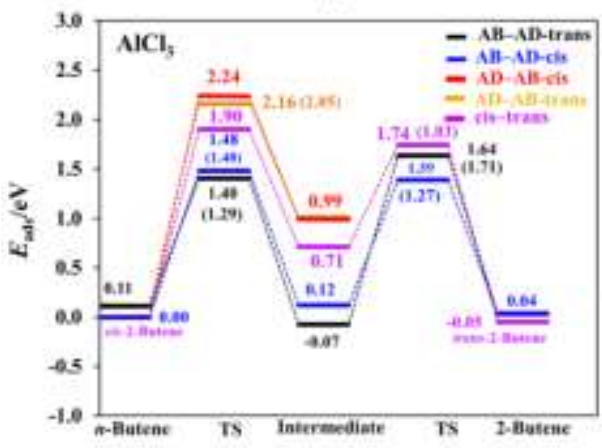

(b)

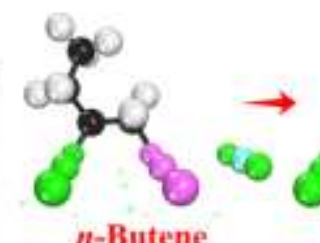

n-Butene

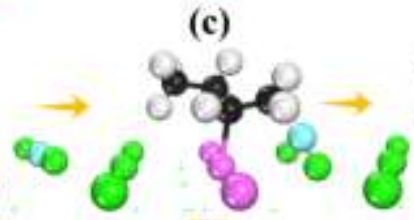

TS

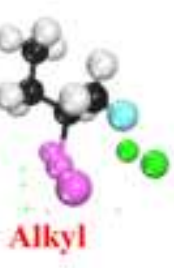

Alkyl

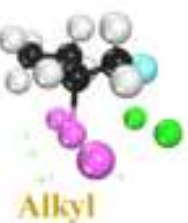

(d)

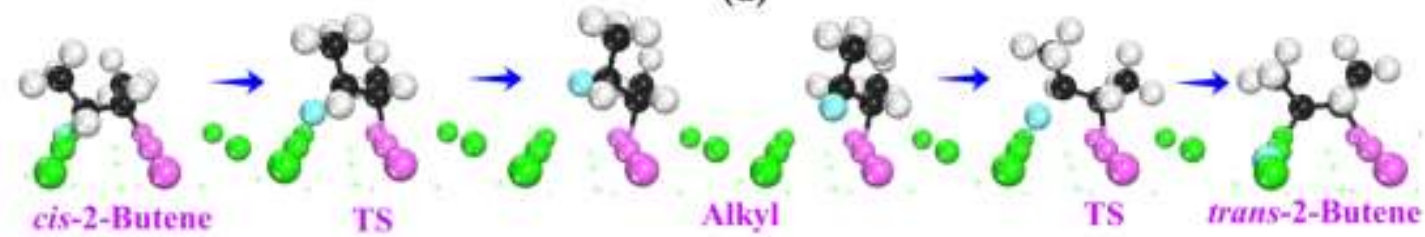

Fig. S14. (a) Energy profiles of $n$-butene isomerization reactions obtained from DFT calculations on LAS of $\mathrm{AlCl}_{3} @ \gamma-\mathrm{Al}_{2} \mathrm{O}_{3}$, the energy barriers are given in the parentheses; (b) the structures in $\mathrm{AD}-\mathrm{AB}$-cis route; (c) the structures in $\mathrm{AD}-\mathrm{AB}$-trans route; (d) the structures in cis-trans isomerization reaction.
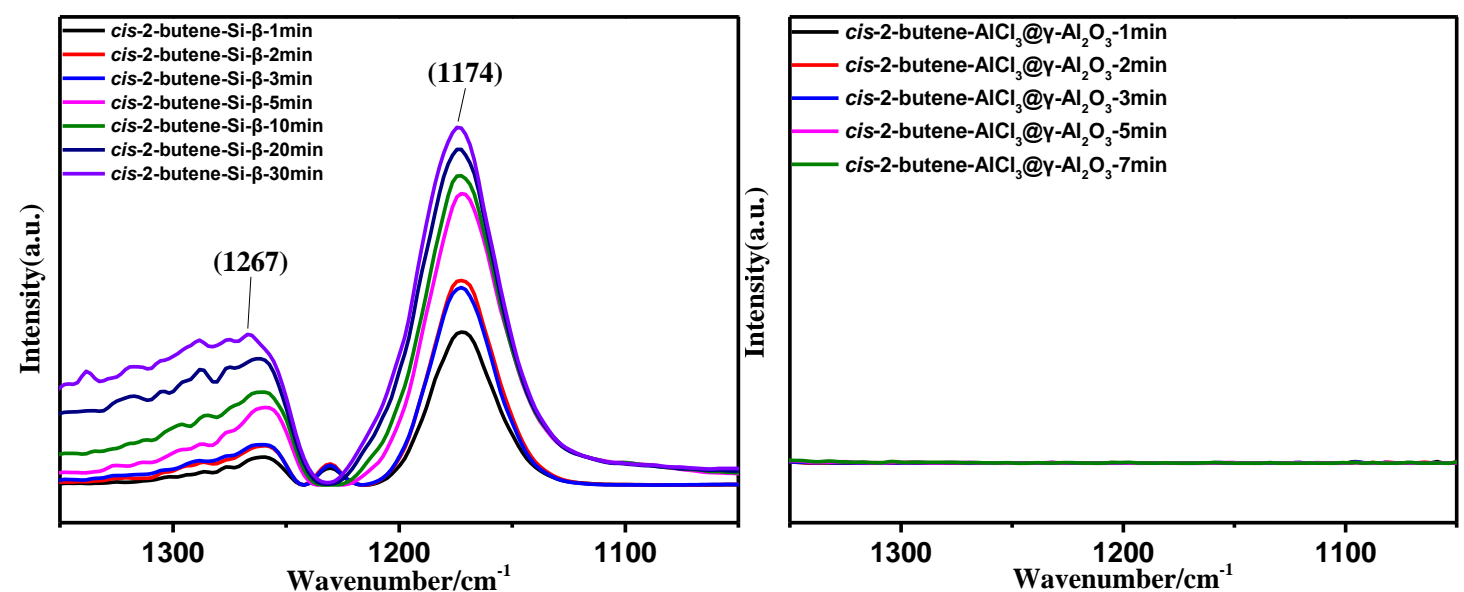

Fig. S15. DRIFT spectra of alkoxyl group of cis-2-butene adsorbed on Si- $\beta$ and $\mathrm{AlCl}_{3} @ \gamma-\mathrm{Al}_{2} \mathrm{O}_{3}$ at $30{ }^{\circ} \mathrm{C}$. 

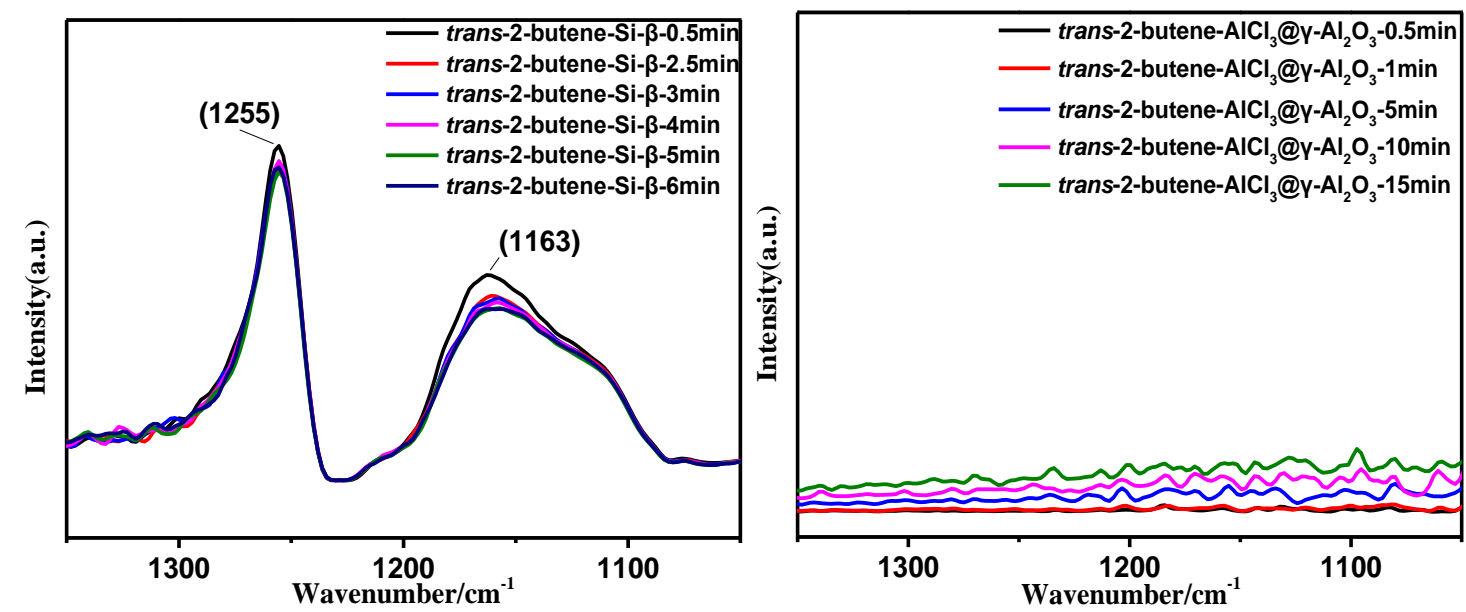

Fig. S16. DRIFT spectra of alkoxyl group of trans-2-butene adsorbed on Si- $\beta$ and $\mathrm{AlCl}_{3} @ \gamma-\mathrm{Al}_{2} \mathrm{O}_{3}$ at $30{ }^{\circ} \mathrm{C}$.

\section{DRIFTS Investigation of Reaction Mechanism of trans-2-Butene on LASs:}

Considering the thermodynamic stability of trans-2-butene and the different activities of the catalysts, we performed the adsorptions of trans-2-butene on Si- $\beta$ and $\mathrm{AlCl}_{3} @ \gamma-\mathrm{Al}_{2} \mathrm{O}_{3}$ at $100{ }^{\circ} \mathrm{C}$ in an open system and $60{ }^{\circ} \mathrm{C}$ in a closed system, respectively (Fig. S17).
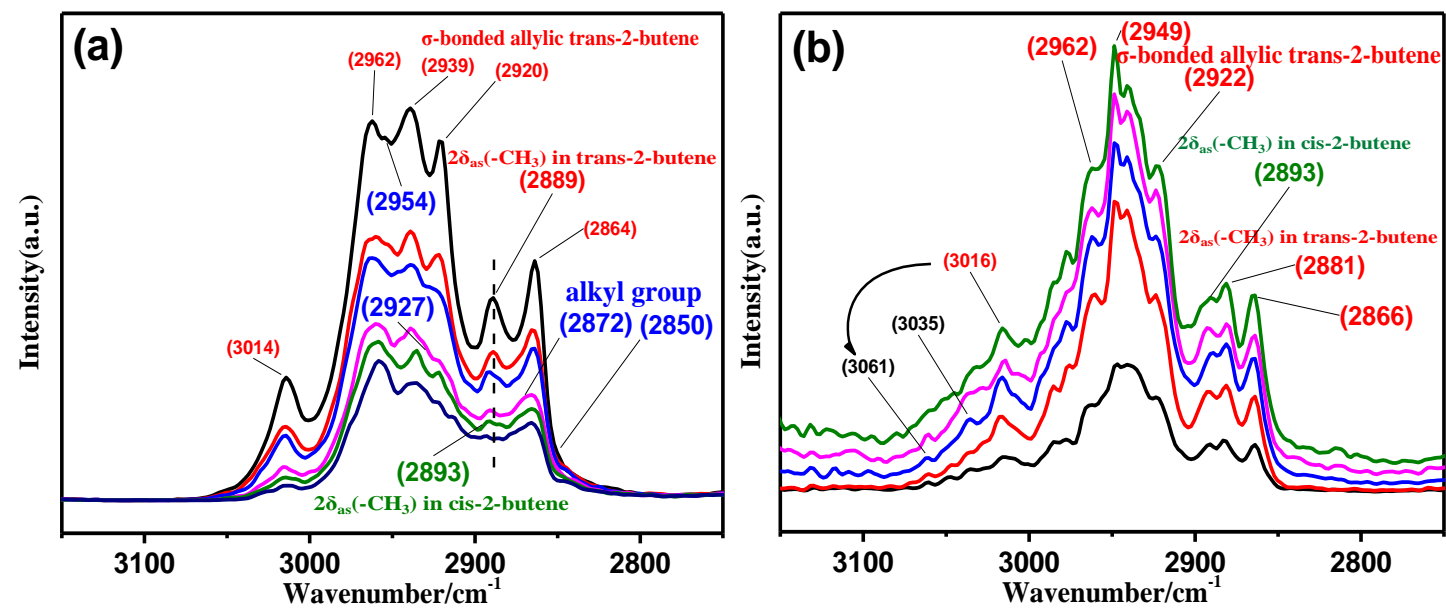

Fig. S17. DRIFT spectra of trans-2-butene adsorbed on (a) Si- $\beta$ at $100{ }^{\circ} \mathrm{C}$ in open system and (b) $\mathrm{AlCl}_{3} @ \gamma-\mathrm{Al}_{2} \mathrm{O}_{3}$ at $60{ }^{\circ} \mathrm{C}$ in closed system. From top to bottom in each panel: (a) 0.5, 2.5, 3, 4, 5, and $6 \mathrm{~min}$; and (b) 0.5, 1, 5, 10, and $15 \mathrm{~min}$.

The adsorption of trans-2-butene on $\mathrm{Si}-\beta$ was performed in an open system at a relatively high temperature of $100{ }^{\circ} \mathrm{C}$. This promotes the conversion of trans-2-butene. For trans-2-butene adsorbed on silanol, $\sigma$-bonded allylic trans-2-butene was formed in the initial stage, as confirmed by the bands at $3014(v=\mathrm{CH}), 2962 / 2939\left(v_{\mathrm{as}}-\mathrm{CH}_{3}\right)$, $2920\left(v_{\mathrm{s}}-\mathrm{CH}_{3}\right)$, and 2889/2864 $\left(2 \delta_{\mathrm{as}}-\mathrm{CH}_{3}\right) \mathrm{cm}^{-1}$ (Fig. S17a). However, $\sigma$-bonded 
allylic trans-2-butene is not the intermediate species in the direct conversion of trans-2-butene to cis-2-butene. A signal from cis-2-butene at $2893 \mathrm{~cm}^{-1}\left(2 \delta_{\mathrm{as}}-\mathrm{CH}_{3}\right)$ appears along with alkyl group bands at $2954\left(v_{\mathrm{as}}-\mathrm{CH}_{3}\right), 2927\left(\mathrm{v}_{\mathrm{as}}-\mathrm{CH}_{2}\right), 2872$ $\left(v_{\mathrm{s}}-\mathrm{CH}_{3}\right)$, and $2850\left(v_{\mathrm{s}}-\mathrm{CH}_{2}\right) \mathrm{cm}^{-1}$. A hydrogen from silanol in $\mathrm{Si}-\beta$ is added to the double bond in trans-2-butene (Scheme 1a) to generate an alkyl group, which has a rotatable $\mathrm{C}-\mathrm{C}$ bond and enables trans-cis isomerization.

On $\mathrm{AlCl}_{3} @ \gamma-\mathrm{Al}_{2} \mathrm{O}_{3}$, the rapid appearance of $\sigma$-bonded allylic trans-2-butene is shown by the IR bands at 2962/2949 $\left(v_{\mathrm{as}}-\mathrm{CH}_{3}\right), 2922\left(v_{\mathrm{s}}-\mathrm{CH}_{3}\right)$, and 2881/2866 $\left(2 \delta_{\mathrm{as}}-\mathrm{CH}_{3}\right) \mathrm{cm}^{-1}$. The signal at $2893 \mathrm{~cm}^{-1}$, which is assigned to $2 \delta_{\mathrm{as}}-\mathrm{CH}_{3}$ in cis-2-butene, indicates that the product is generated clearly and rapidly without alkyl group formation. Two processes are involved: conversion of trans-2-butene to $n$-butene via a $\sigma$-bonded allylic trans-2-butene intermediate, and $n$-butene conversion to cis-2-butene via $\sigma$-bonded allylic $n$-butene (Fig. S17b, $3061 \mathrm{~cm}^{-1}$ ).

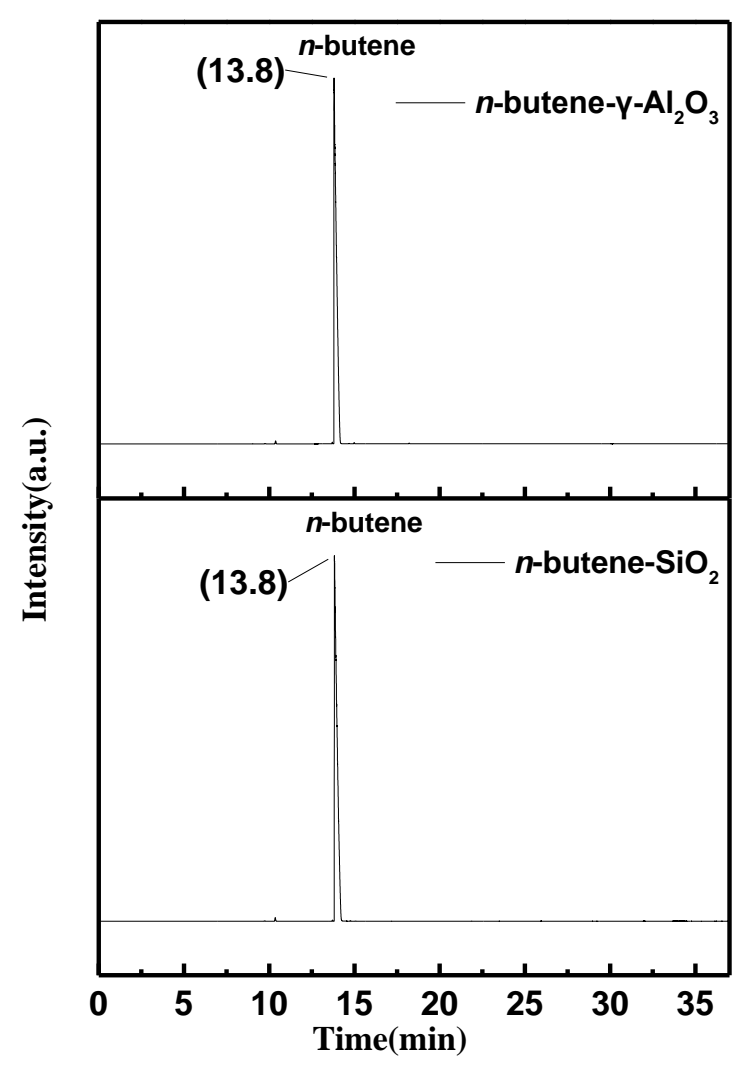

Fig. S18. Chromatographs of $n$-butene isomerization reactions on $\mathrm{SiO}_{2}$ and $\gamma-\mathrm{Al}_{2} \mathrm{O}_{3}$ at $100^{\circ} \mathrm{C}$ with a WHSV of $0.2 \mathrm{~h}^{-1}$. 


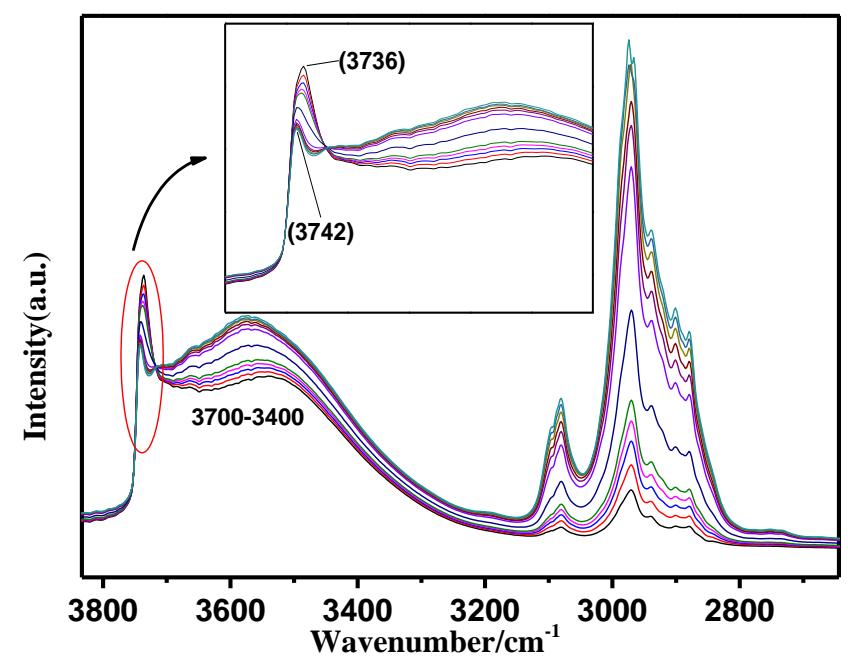

Fig. S19. In situ FI-IR spectra of $n$-butene feeding on Si- $\beta$ continuously at $100^{\circ} \mathrm{C}$ with a WHSV of $0.75 \mathrm{~h}^{-1}$ as a background of flowing helium gas. From bottom to top: 1-5, 10, 20, 25, 20, 35, 30 and $45 \mathrm{~min}$.

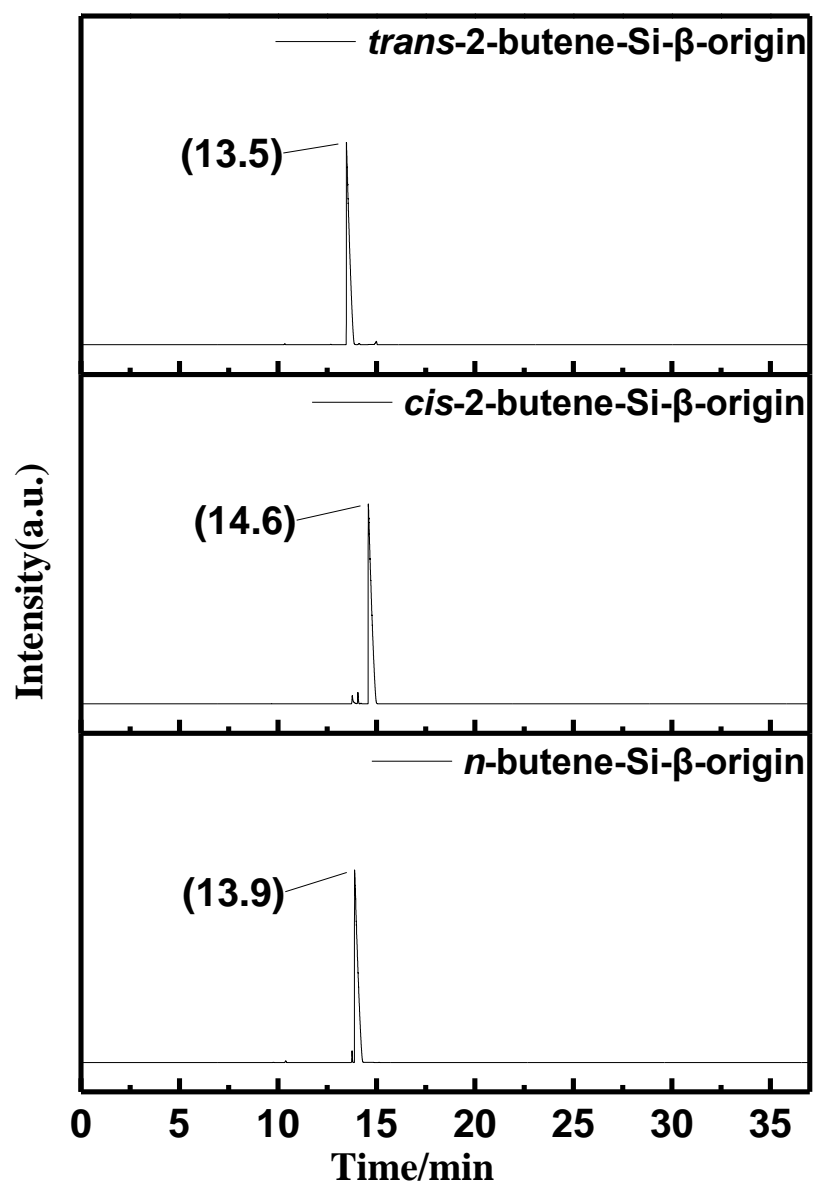

Fig. S20. Chromatographs of $n$-butene, cis-2-butene and trans-2-butene isomerization reactions on Si- $\beta$-origin at $100^{\circ} \mathrm{C}$ with a WHSV of $0.2 \mathrm{~h}^{-1}$. 

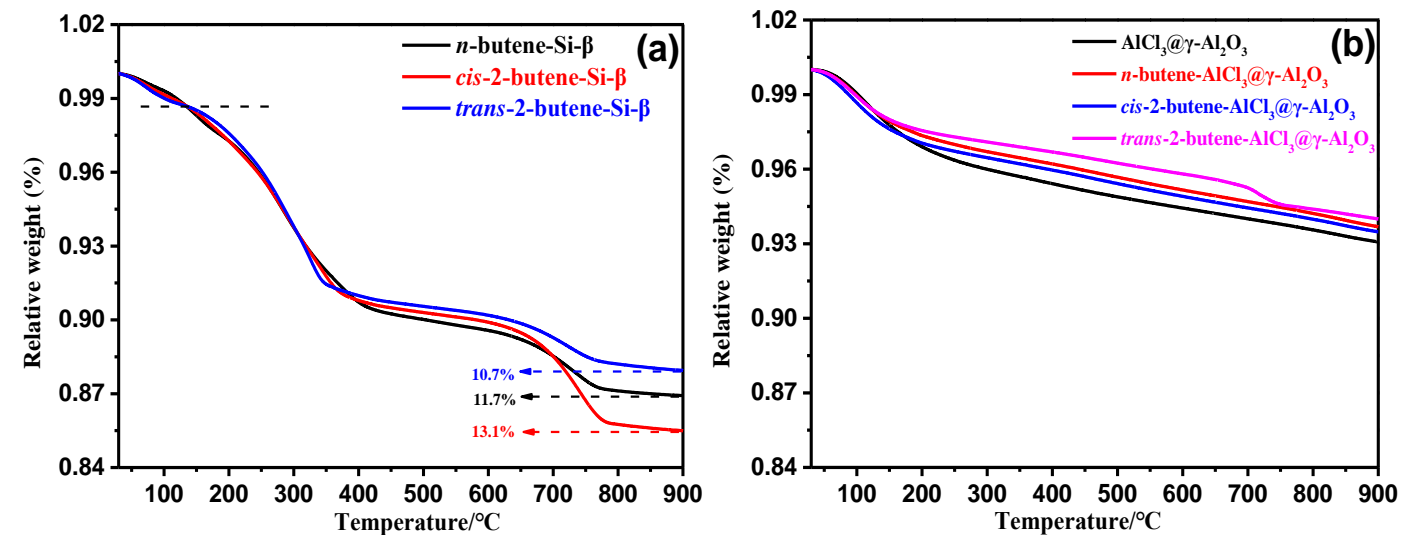

Fig. S21. TG curves of catalysts (a) Si- $\beta$ and (b) $\mathrm{AlCl}_{3} @ \gamma-\mathrm{Al}_{2} \mathrm{O}_{3}$ after reaction for 3.4 h. The weight loss percentages over temperature $150{ }^{\circ} \mathrm{C}$ are labled.

\section{Note:}

This information is available free of charge on the ACS Publications website.

\section{REFERENCES}

(1) Barnes, A. J.; Howells, J. D. R. Infra-red cryogenic studies. Part 12.-alkenes in argon matrices. J. Chem. Soc., Faraday Trans. 2. 1973, 69, 532-539.

(2) Mckean, D. C.; Mackenzie, M. W.; Morrisson, A. R.; Lavalley, J. C.; Janin, A.; Fawcett, V.; Edwards, H. G. M. Vibrational spectra of cis and trans but-2-enes: assignments, isolated $\mathrm{CH}$ stretching frequencies and CH bond lengths. Spectrochim. Acta, Part A. 1985, 41, 435-450.

(3) Bellamy, L. J., The Infra-red Spectra of Complex Molecules. 1980.

(4) Gao, S.; Moffat, J. B. An Infrared spectroscopy study of 1-butene and its isomers adsorbed onto 12-tungstophosphoric acid/SiO ${ }_{2}$. Colloids Surf., A. 1995, 105, 133-142.

(5) Förster, H.; Seelemann, R. Gas-isomerization of $n$-butenes on A-type zeolites studied by infrared sectroscopy. Part 1. $-n$-Butene adsorption on zeolites containing alkali and alkaline earth cations. J. Chem. Soc. Faraday Trans. 1. 1978, 74, 1435-1443.

(6) Förster, H.; Seelemann, R. Isomerization of $n$-butenes on A-type Zeolites studied by infrared spectroscopy. Part 3.-Adsorption and isomerization of $n$-butenes on zeolites containing transition metal ions. J. Chem. Soc. Faraday Trans. 1.1981, 77, 1359-1370.

(7) Zhao, Z.; Xu, S.; Hu, M. Y.; Bao, X.; Peden, C. H. F.; Hu, J. Investigation of aluminum site changes of dehydrated zeolite $\mathrm{H}-\beta$ during a rehydration process by high-field solid-state NMR. $J$. Phys. Chem. C. 2015, 119, 1410-1417. 